\title{
An Interview with Oskar Negt (2004)
}

\author{
Kerstin Pohl and Klaus-Peter Hufer
}

\section{Introduction}

Oskar Negt is an emeritus professor of sociology at the University of Hannover and a prolific writer, best known in the Anglophone world for two books written with the film maker and novelist Alexander Kluge: Public Sphere and Experience: Toward an Analysis of the Bourgeois and Proletarian Public Sphere, published in Germany in 1972 and in the United States in 1993 (then reissued by Verso Books in 2016), and History \& Obstinacy, which appeared in Germany in 2008 and in an English translation from Zone Books in 2014. In addition to his sociological and theoretical reflections, however, Negt is also a well-known worker educator, whose first major publication in 1971 was Soziologische Phantasie und exemplarisches Lernen: Zur Theorie und Praxis der Arbeiterbildung [Sociological Imagination and Exemplary Learning: On the Theory and Practice of Workers' Education], which has never been translated into English. Soziologische Phantasie und exemplarisches Lernen was an influential, widely read text that provoked considerable discussion in European workers' education circles, some of which can be followed in the 1978 anthology edited by Adolf Brock, Hans Dieter Müller, and Oskar Negt entitled Arbeiterbildung: Soziolgische Phantasie und Exemplarisches Lernen in Theorie, Kritik und Praxis [Workers' Education: Sociological Imagination and Exemplary Learning in Theory, Critique and Practice].

The exchange below, translated by Sascha Hosters, is excerpted from an interview with Oskar Negt by Kerstin Pohl and Klaus-Peter Hufer entitled "Politische Bildung ist die Befreiung der Menschen," from Positionen der Politischen Bildung 2: Ein Interviewbuch zur ausserschulischen Jugend- und Erwachsenenbildung, ed. Klaus-Peter Hufer (Bonn, 2004), 196-213.

Kerstin Pohl: Please begin by telling us how and why you got involved in political education for adults and the biographical reasons or key experiences that motivated you to do so.

Oskar Negt: That is how I was brought up politically in my family. My father was active in the Workers and Soldiers Councils of 1918, a member of the Social Democratic Party (SPD), and a small farmer. My family background was divided between a rural and a proletarian existence, and I had an early connection to the SDP. I became a member of the SPD after graduating from high school, and while continuing my studies, I joined with union contacts to rebuild the education department at IG Metall. Since I was already involved in this area as a student, Hans Matthöfer, who had come from the 
US for this purpose, then asked me to work with the Confederation of German Trade Unions (DBG) union school.

From my experience teaching work committees and shop stewards, I became aware that the unions were not offering political education classes. What was being taught were legal relationships and the law. District attorneys were being brought to the DBG national school in Oberusel and when we-leftleaning students-looked at what they actually did, we got really sick of it. They brought shop stewards from the "old school" into the classes so that the new stewards and members of the worker council received some information on labor law and the constitution, etc. But they generally learned nothing about the political system. After this experience I decided to develop my own concept of didactic political education, which is how my book Soziologische Phantasie und Exemplarisches Lernen [Sociological Imagination and Exemplary Learning] came to be written. Therefore, my key experience was practical.

Pohl: To what extent do you see yourself explicitly as a political educator, especially as a sociologist?

Negt: Very explicitly. I believe that education is an existential necessity in our society. Democracy is the only form of government that has to be learned, while all other forms of government do not. Dictatorships or a system of terror repress political education. For me, all real education is political.

Klaus-Peter Hufer: How do you assess the contemporary situation and the perspectives of political education for adults or extracurricular education for adolescents? How do you view its position in society? What are the greatest challenges for political education in your opinion?

Negt: There is an ideology of business, a logic of capital and markets, which permeates all areas of education except those that are immediately useful in a technical sense or have only to do with make-believe. Political education takes place in the tension between individual interests, individual desires, and what is generally called the community. Especially in the contemporary situation, those levels of social reality in which individual experiences, interests, and needs are given a communal expression are disappearing. This translation between the individual and the communal presupposes what I call "livable units" [lebbare Einheiten], intermediate levels of society where proximity and distance are balanced, which have to come much more to the fore. But these kinds of spaces specifically fall victim to the general rationalization of society. These include spaces where adolescents can meet up without being watched and controlled; also the many ways in which, for instance, in a bank, human relationships are connected with communities. All these are falling victim to the economic rationalization of society. 
Hufer: What do you think is the role of political education, specifically adult and adolescent education in the future?

Negt: I believe that it will have a central role in the European unification process, which cannot progress on the same assumptions as the unsuccessful attempt to unify the two Germanies. In the latter case, what belonged together did not really grow together naturally.

The range of political education in European countries is very disparate. The Nordic countries have a great tradition of popular education descending from Grundtvig. In contrast, there are other countries where there is little or no political education. In Italy, certainly, trade union education is very strong, but it is nonexistent in Spain. I think that political education is essential to European unification, that political education must be central to a European-wide tradition because-to repeat one more time-democratic behavior is not inborn but has to be learned.

Hufer: This leads to the next fundamental question: What does education mean for you?

Negt: Okay! It is definitely not identical to learning. Learning is a kind of knowledge, it is knowing how to acquire information. Going beyond learning as the acquisition of information is not just learning to learn. Learning to learn simply means that processing knowledge and information have become second nature. When I speak of education, I mean learning to evaluate and select information in the context of the whole. Education, for me, is making connections. And because we are living in a dynamic society with democratic aspirations, education means looking at the whole of society, including its power structures and its governing structures. This has many levels, including mental, emotional, and social development. In my view, all three of these areas of learning-cognitive, emotional, and social-belong to my concept of education. But they have very, very different time structures or temporalities. If a child or an adult cannot really deal with their own emotions, this inability will have an impact on their cognitive capacity. I have plenty of students who are cognitively outstanding but cannot finish their work, for instance. As for social skills: "How do I compromise?" "How do I negotiate?" "How do I learn to share without believing that sharing puts me at a disadvantage?" In other words, to share, to compromise, and to negotiate are social competencies which are central to education. If these things are not being learned, one is left with only a pale, much reduced notion of education.

Pohl: How do you understand politics? Do you have a rather narrow or broad conception of politics? 
Negt: It is a very broad conception. In Plato, politics means "matters of concern to the community," that is to say, issues that are of concern to the polis, to the community. These could include hunger as well as the significance of immigration for society. Politics is a way of thinking and acting about social categories and the particular conditions under which we live. I oppose a narrow definition of politics as something that is just about the state. Max Weber, for instance, understood politics in relation to the acquisition and preservation of political power, which for him can only be imagined in the context of the state. This definition is too narrow for me, because many of the things that eventually become law start out as small, invisible molehills and then become great movements. Politically relevant protest began as a small movement.

Hufer: After discussing the basic requirements of an education and a broad concept of politics, we now come to the goal of political education. What does all this have to do with the practice of political workers' education? Which methods of teaching and learning are suitable to the realization of your objective?

Negt: This might seem a bit conceited, and, of course, no one likes to admit when they are older that they were wrong earlier, but I still think that "exemplary learning," where there is a fresh dialectic between the general and the specific, is the only method suited to reaching this part of society. Let me explain briefly: I believe that incorporating people's own interests and associations into the educational process is very useful for learning and education to be successful. Because otherwise their issues are ignored. This is my basic thesis about exemplary learning: no education can avoid involving people's own interests in its learning process. Working through their contradictions, prejudices, and confusions must be in the foreground. In the present social situation, and this will grow stronger, education has to produce a general or universal consciousness. Education cannot be reduced to something special or particular. We have to develop something universal from the particular. Doing so prevents society from being fragmented into different experiential worlds or risk environments. To develop the universal from the particular is, for Kant, an instance of our faculty of reflective judgment. It means that one takes a universal law and then looks to subsume instances under it. It is an ability to make judgments and is no big deal. It is not what Kant meant by enlightenment or education. I later discovered the same thought in Hannah Arendt, who developed a political philosophy along these lines from Kant's faculty of judgment. I think this is very true. We no longer have universal laws available as a system of ideals, as we mistakenly thought Marxism to contain. Insofar as I would like to update and deepen my work on "exemplary learning," I would like to include a long chapter on rhetoric. I believe the ability of the emancipatory left to effect transformative change is now very low. Which also means that the rhetorical 
tradition is part of the work of transformation. Here I go back to Cicero and Aristotle and try to actualize how earlier social orders dealt with the fact that knowledge and truth do not prevail on their own but must be mediated or contextualized.

Hufer: How would you describe "good" political education?

Negt: Good political education consists of a participant leaving a class or event and beginning to think for themselves. After the class someone can say, "Finally, I have something like a key to lived experience, a key with which I can judge the world and my place in it." 